\title{
Critical processes in the formation of contact-style PGE-Ni-Cu mineralization: Evidence from the Gabbro-10 intrusion as an additional intrusive phase of the Paleoproterozoic Monchegorsk Complex
}

\author{
P. V. Pripachkin ${ }^{1}$, N. Yu. Groshev ${ }^{1 *}$, B. T. Karykowski ${ }^{2}$ \\ ${ }^{1}$ Geological Institute, Kola Science Centre, Russian Academy of Sciences, 184209 Apatity, Russia \\ 2 Fugro Germany Land GmbH, Resource Consulting, 12555 Berlin, Germany \\ *Corresponding author e-mail: nikolaygroshev@gmail.com
}

\begin{abstract}
Summary Several studies on the Monchegorsk Complex suggest that the gravitational accumulation of sulfide droplets enriched in platinum group elements (PGE) near the bottom of the magma chamber under the condition of preliminary heating of the host rocks by early intrusive phases is a key process in the formation of contact-style PGE-copper-nickel mineralization. Using the example of Gabbro-10 intrusion, which is a late low-volume magmatic phase of the Monchegorsk Complex, we aim to demonstrate the importance of magma enrichment with sulfides occurring at depth in intermediate magma chambers. Moreover, this work substantiates the PGE prospectivity of the Gabbro-10 intrusion and its prospects for scientific drilling.
\end{abstract}

\section{Introduction and background to current research}

As a result of our previous studies of outcrops and drill holes on a drill section in the western part of the Gabbro-10 intrusion (Fig. 1), it was possible to establish the following general features of its geological structure and ore mineralization. The Gabbro-10 intrusion is located near the southern contact of the Nyud-Poaz intrusion of the Paleoproterozoic Monchegorsk Complex $(2.5 \mathrm{Ga})$ and represents a flattened subhorizontal metagabbro lens hosted by Archean diorites. The metagabbros are covered with metadiorites separating these rocks from the melanorites of the Nyud-Poaz intrusion. The profile of the Gabbro-10 massif can be subdivided into two zones: (1) marginal zone and (2) gabbro zone. The marginal zone, up to $10 \mathrm{~m}$ thick, is composed of fine- to medium-grained schistose metagabbro, geochemically similar to mesocratic gabbronorites (Groshev et al., 2018a) according to classification (Dubrovsky, 2002). The gabbro zone consists of coarse- to medium-grained metagabbro, often characterized by taxitic texture due to the alternation of rocks with different grain sizes. The thickness of the zone is $30-40 \mathrm{~m}$, increasing towards the east reaching up to $80 \mathrm{~m}$. The geochemical composition of the metagabbro corresponds to quartz mesoleucocratic gabbronorite. The metagabbro contains xenoliths up to $10 \mathrm{~m} \times 15 \mathrm{~m}$ in size. In terms of structural and textural features as well as geochemical composition, most of the xenoliths correspond to melanorite from the NyudPoaz intrusion and its endocontact zone (Groshev et al., 2018a). The metagabbro overlaps with the so-called metadiorite, at the base of which a magnetite layer of 1-2 $\mathrm{m}$ thickness is present. It is believed that the metagabbro and the metadiorite represent differentiates of the same intrusion. The U-Pb isotope age of the metagabbro is $2497 \pm 9 \mathrm{Ma}$ (unpublished data), whereas the age of the metadiorite is $2498 \pm 6 \mathrm{Ma}$ (Groshev et al., 2018b), which is within error and coincides with an isotope age of $2504 \pm 2$ Ma for the Nyud-Poaz intrusion (Amelin et al., 1995). Despite the indistinguishability of isotope ages at a given accuracy, the Gabbro-10 intrusion is clearly a late differentiated magmatic phase of the Monchegorsk Complex.

The PGE-Cu-Ni mineralization of the Gabbro-10 intrusion is associated with unevenly distributed and nested areas of disseminated sulfide (Groshev and Pripachkin, 2018). The dissemination is mainly confined to the marginal zone, but often spreads into the metagabbro 
and diorites of the basement. The sulfide content varies from single grains to 10 vol. \%. The Pd concentration in the schistose metagabbro of the marginal zone is $0.58 \mathrm{ppm}$ (drill hole 1808), whereas the metagabbro contains $1.78 \mathrm{ppm}$ (sample G181-1 from the outcrop). The basement diorites show up to $2.28 \mathrm{ppm} \mathrm{Pd}$ (drill hole 1809). The Ni content in only a few samples of schistose metagabbro and basement diorites exceeds $0.1 \mathrm{wt} . \%$ with a relatively high $\mathrm{Cu} / \mathrm{Ni}$ ratio. It is worth noting that according to the results of historic drilling for nickel carried out by S.M. Rutshtein and colleagues (1964) in the southwestern and eastern parts of the massif, there are two copper-nickel "ore stocks" (Fig. 1) confined to the bottom of the Gabbro-10 intrusion. The nickel concentration of these ore stocks varies from 0.2 to $0.9 \mathrm{wt} . \%$, reaching $1.3 \mathrm{wt}$. $\%$ at most. Since these "ore stocks" were not drilled during PGE exploration in the Monchegorsk Complex, the concentration of precious metals remains unknown.
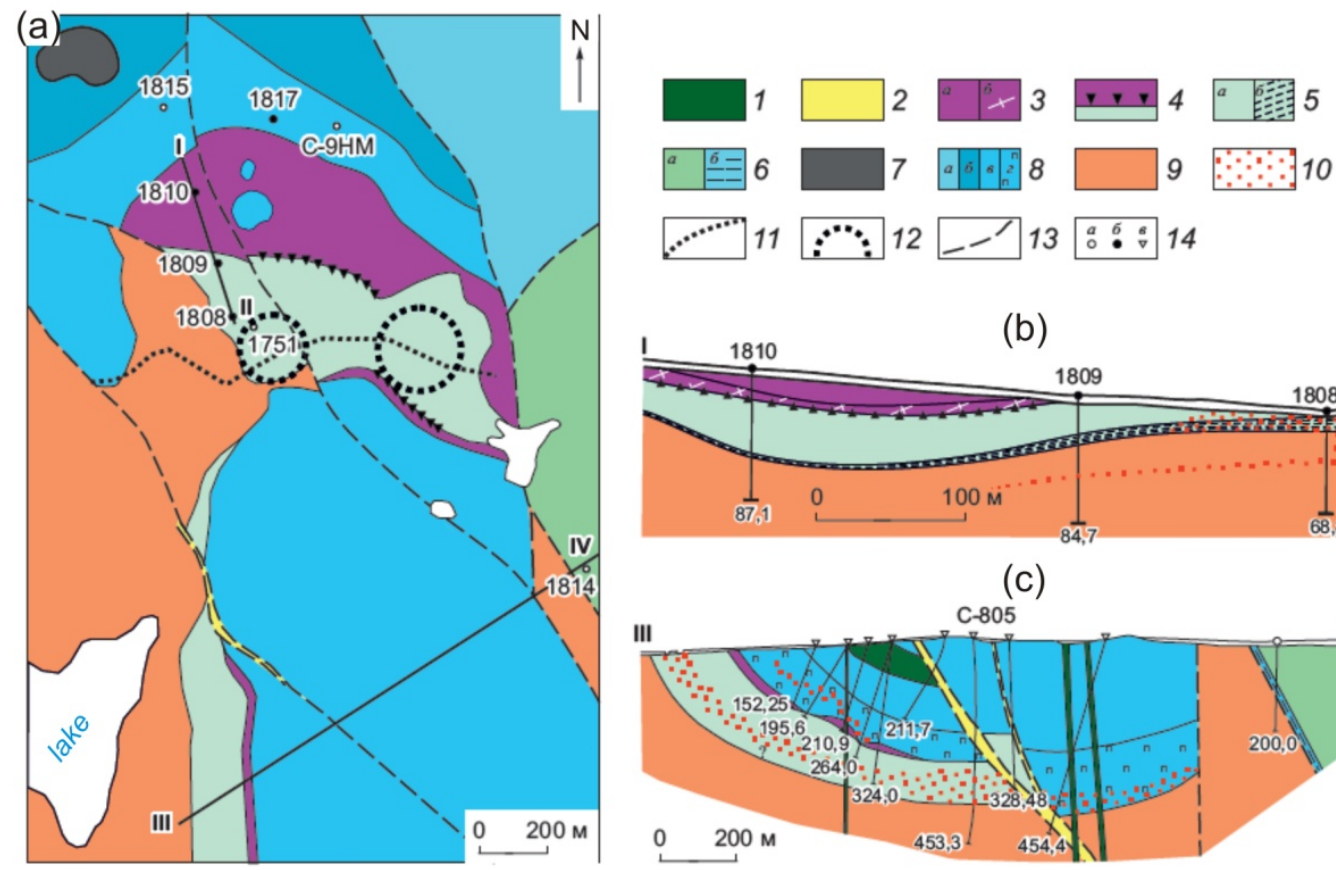

(b)

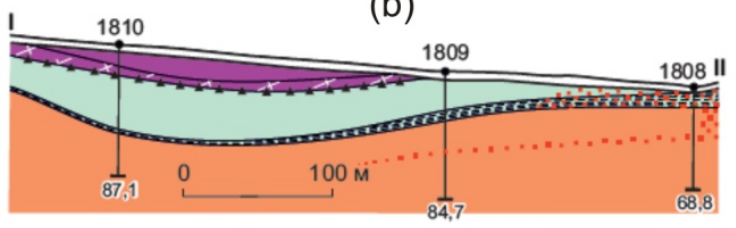

(c)

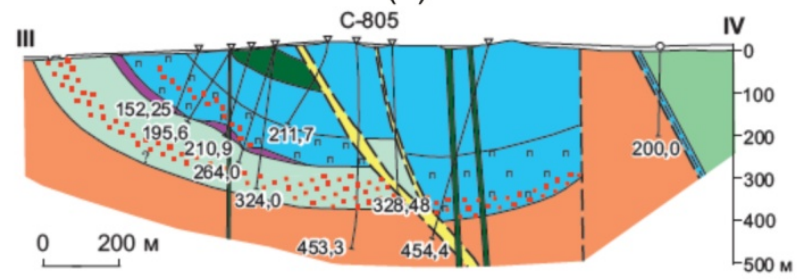

Figure 3. Schematic geological map (a) and simplified geological sections of the Gabbro-10 intrusion (b) and the Upper Nyud block (c) (Groshev and Pripachkin, 2018). 1 - metagabbrodolerite; 2 - tectonic zone; 3 - metadiorite (a), alternation of metadiorite, basement diorite and magnetite rocks (б); 4 magnetite rock; 5 - Gabbro-10 intrusion (a - metagabbro, $\sigma$ - schistose metagabbro); 6 - Vurechuaivench massif (a - metagabbronorite, $\sigma$ - schistose metanorite); the Nyud-Poaz intrusion and the Upper Nyud block: 7 - critical horizon, 8 - norite (a), olivine norite (б), melanocratic norite (в), porphyritic melanorite (г); 9 - basement diorite; 10 - sulfide dissemination; 11 - 10th anomaly of electrical conductivity of the Monchegorsk ore region; 12 - approximate contours of copper-nickel ore stocks; 13 - faults; 14 - drill holes (a - assayed for PGE, 6 - studied by the authors, B - assayed only for base metals)

\section{Research questions at hand}

The confinement of the PGE-Cu-Ni mineralization at the bottom of the Gabbro-10 intrusion and its migration into the basement rocks by tens of meters (Fig. 2) indicate the critical role of gravitational sulfide drainage according to the mechanism described in Karykowski et al. (2018). A favorable factor for sulfide drainage in the Gabbro-10 intrusion is the thermal effect of the early magmatic phase represented by the larger Nyud-Poaz intrusion shortly before the emplacement of the Gabbro-10 intrusion. However, it could be assumed that one of the key roles or even the main role in the formation of the PGE-Cu-Ni mineralization of the Gabbro-10 intrusion is the enrichment of the magmatic crystal mush with sulfides and PGE in an 
intermediate magma chamber at depth. This assumption is supported by the numerous small vein bodies of quartz gabbronorites in the South Sopcha intrusion and the Moroshkovoye Ozero area located nearby (Pripachkin et al., 2016). Veins of quartz gabbronorites contain sulfide (3\%), magnetite (3\%) and nests of disseminated sulfide enriched in PGE reaching 6-8 ppm. It is highly probable that these veins are co-magmatic with the Gabbro-10 intrusion, which can be proved by high-precision isotope dating. An indirect confirmation of the enrichment of magmatic mush with metals at depth is the similarity of the breccia-like Gabbro-10 intrusion and the basal breccia of the Fedorova intrusion (Schissel et al., 2002; Groshev et al., 2019). The difference between the Gabbro-10 intrusion and the basal breccia at Fedorova is that the latter has a relatively uniform thickness in disseminated sulfide mineralization over hundreds of meters, containing up to $8 \mathrm{ppm}$ PGE (1.2 on average). This is explained by a large time gap of more than 700,000 years (Groshev et al., 2009; Groshev et al., 2021). This temporal gap contributed to the cooling of the early intrusive phase. As a result, the pronounced sulfide migration in the additional magmatic phase, which is evidenced by the Gabbro-10 intrusion, did not occur at Fedorova.

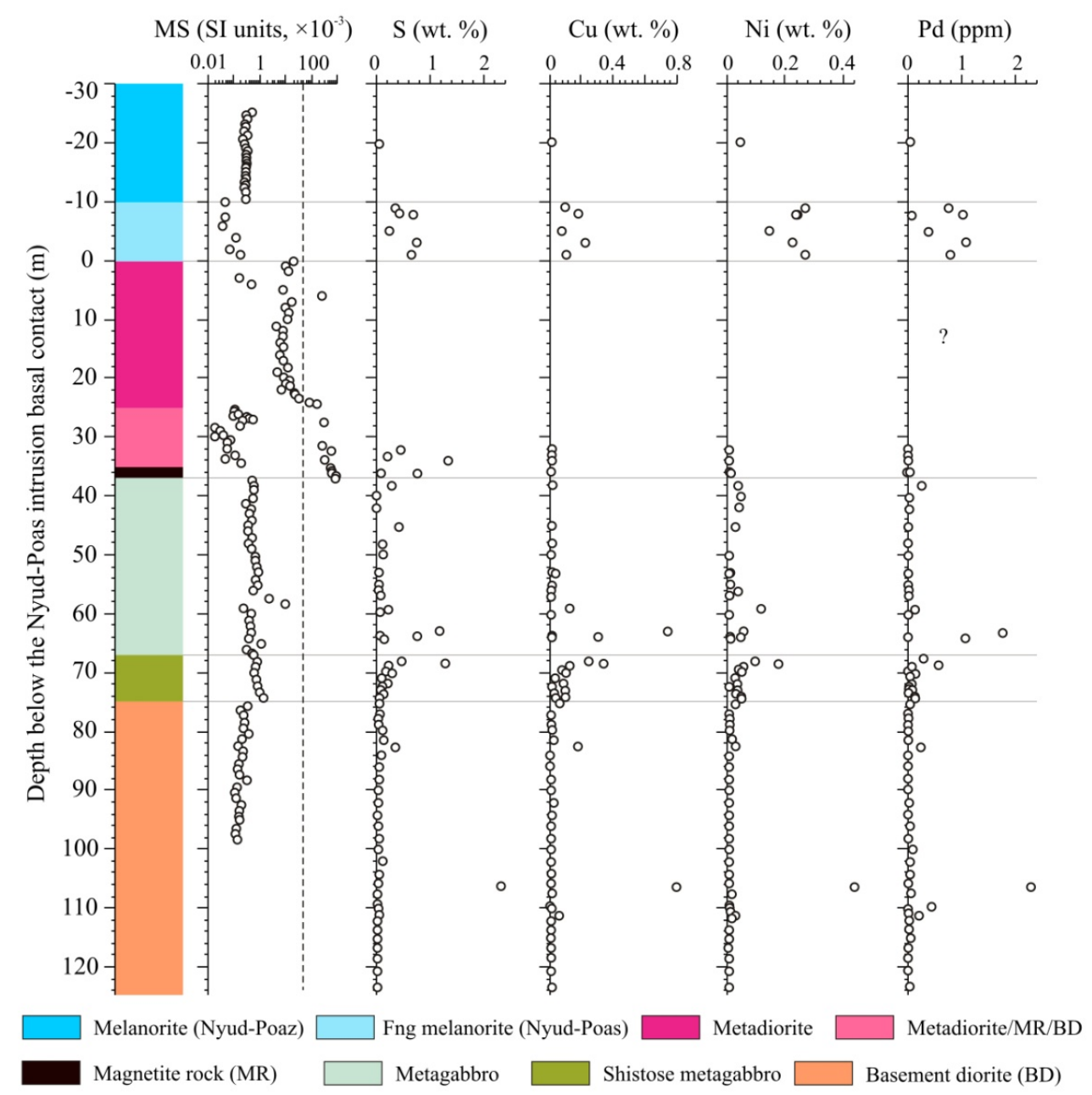

Figure 2. Simplified stratigraphic column across the Gabbro-10 intrusion with variations of magnetic susceptibility (MS) and S, Cu, Ni and Pd concentration (Groshev and Pripachkin, 2018).

\section{Future prospects}

To prove the co-magmatic nature of the gabbroids of the Gabbro-10 intrusion and vein quartz gabbronorites with sulfides and abundant magnetite, it is planned to conduct a comparative 
geochemical study to determine the concentration of lithophile and chalcophile elements in rocks (100 samples), analyze the composition of trace elements in sulfide and magnetite by LAICP-MS (20 samples), study the isotope composition of $\mathrm{Sm}, \mathrm{Nd}$ and $\mathrm{S}$ in rocks (30 samples) and perform high-precision $\mathrm{U}-\mathrm{Pb}$ isotope zircon dating using CA-TIMS (5 samples). From an economic point of view, the most important results will be obtained from drilling one or two holes up to $200 \mathrm{~m}$ deep in the area of the sulfide ore stocks with Ni contents up to $1.3 \mathrm{wt}$. \%.

\section{Acknowledgements}

The research was supported by the Ministry of Science and Higher Education of the Russian Federation (project 0226-2019-0053).

\section{References:}

Amelin YV, Heaman LM, Semenov VS (1995) U-Pb geochronology of layered mafic intrusions in the eastern Baltic Shield: implications for the timing and duration of Paleoproterozoic continental rifting. Precambrian Res 75:31-46. https://doi.org/10.1016/0301-9268(95)00015-W

Dubrovsky MI (2002) Complex classification of magmatic rocks. Apatity Publ KNTs RAS 234

Groshev NY, Nitkina EA, Mitrofanov FP (2009) Two-phase mechanism of the formation of platinum-metal basites of the Fedorova Tundra intrusion on the Kola Peninsula: New data on geology and isotope geochronology. Dokl Earth Sci 427:1012-1016. https://doi.org/10.1134/S1028334X09060270

Groshev NY, Pripachkin PV (2018) Geological setting and platinum potential of the Gabbro-10 massif, Monchegorsk Complex, Kola Region. Ores Met 4-13. https://doi.org/10.24411/0869-5997-2018-10008

Groshev NY, Malygina AV, Timofeeva MG (2018a) Nature of high-magnesian xenoliths of the Gabbro-10 intrusion, Monchegorsk Complex, Kola Region. Vestn MSTU 21:5-17

Groshev NY, Pripachkin PV, Karykowski BT, et al (2018b) Genesis of a Magnetite Layer in the Gabbro-10 Intrusion, Monchegorsk Complex, Kola Region: U-Pb SHRIMP-II Dating of Metadiorites. Geol Ore Depos 60:486-496. https://doi.org/10.1134/s1075701518060028

Groshev NY, Rundkvist TV, Karykowski BT, et al (2019a) Low-Sulfide Platinum-Palladium Deposits of the Paleoproterozoic Fedorova-Pana Layered Complex, Kola Region, Russia. Minerals 9:764

Groshev NY, Stepenshchikov DG, Karykowski BT (2021) Thermal modelling of the Paleoproterozoic Fedorova layered intrusion, Kola Region, Russia: implications for the origin of contact-style PGE mineralisation (this volume)

Karykowski BT, Maier WD, Groshev NY, et al (2018) Critical controls on the formation of contact-style PGE-Ni$\mathrm{Cu}$ mineralization: Evidence from the paleoproterozoic Monchegorsk Complex, Kola Region, Russia. Econ Geol 113:911-935. https://doi.org/10.5382/econgeo.2018.4576

Pripachkin PV, Rundkvist TV, Miroshnikova YA, Chernyavsky AV \& Borisenko ES (2016). Geological structure and ore mineralization of the South Sopchinsky and Gabbro-10 massifs and the Moroshkovoe Lake target, Monchegorsk area, Kola Peninsula, Russia. Min Deposita 51(8):973-992 https://doi.org/10.1007/s00126015-0605-0

Schissel D, Tsvetkov AA, Mitrofanov FP, Korchagin AU (2002) Basal Platinum-Group Element Mineralization in the Federov Pansky Layered Mafic Intrusion, Kola Peninsula, Russia. Econ Geol 97:1657-1677. https://doi.org/10.2113/gsecongeo.97.8.1657 